\title{
Research on the Teaching of Computer Aided Design in the Teaching of Environmental Art Design
}

\author{
Kang Shuying \\ College of Arts and Design, Ningbo Dahongying University \\ Ningbo, China
}

\begin{abstract}
Computer-aided design, as a highly technical course, plays an important role in the environment art profession and becomes an important module in the development of vocational skills in the teaching plan. The ultimate goal of computer-aided design is how to use technology to convey design ideas, achieve a balance between technology and art, and enhance design effects. How to make this course play a more effective role in the design of environmental art design is the main content of this paper.
\end{abstract}

Keywords-Teaching Method; Environmental art design; Consideration and research

\section{INTRODUCTION}

Computer-aided courses are compulsory courses for art design and are the main courses for Environmental art design. The production of computer engineering drawings and renderings is closely related to the design of the ring art. It is an important tool for expressing the design details and inspiration of interior and exterior designers. The quality of the teaching of this course directly affects the teaching of the subsequent environmental design course. In order to meet the needs of teaching reform, this paper has carried out a more in-depth analysis of the course, summed up some shortcomings and suggestions for improvement in the teaching status quo.

\section{COMPUTER Aided ENVIRONMENT ART DESIGN COURSE ANALYSIS}

There are two links in computer-aided design in the circle art design. One is to use CAD to draw engineering drawings, and the other is to use $3 \mathrm{ds}$ Max to draw performance renderings. Engineering drawings are the language of engineers and an important part of engineering design and even the entire project construction. The drawing of drawings is an extremely tedious task that requires correctness and precision, and the drawing of a drawing is usually completed after several modifications. With the development of computers, computeraided design came into being. Designers can open the plate to achieve automated drawing, express their design ideas in a simple, beautiful, standard way, easy to modify, easy to reuse, and improve labor efficiency. The renderings are a form of expression that the designer uses to illustrate the design idea. It is both a medium for expressing design intent and a design language for conveying designer emotions and embodying the entire design concept. The computer renderings can be said to be the language of our designers. We need to communicate with our customers to express our design ideas and ideas. It can be seen that in teaching, we should require students to make accurate and reasonable design of engineering drawings with scientific and rigorous attitudes; guide students to convey design connotation in the production of renderings with open thinking, and show the works. Originality and beauty.

\section{CURRENT STATUS AND PROBLEMS OF COMPUTER-AIDED DESIGN TEACHING}

The penetration of computer-aided design technology into the field of art design has only been more than 30 years old. It is also a matter of recent years to introduce China into the practice field of art education. This is undoubtedly the progress of history, the development of art and the reform of education. The result, which indicates that the original hand-painting in art education will be replaced by computer-aided design. The computer design is mainly embodied in the three-dimensional image design of environment and animation based on 3D software such as 3DMAX; the graphic design and twodimensional design of the printing and printing industry using PHOTOSHOP; the computer-aided design using CAD software and FLASH, FIREWORK, DREAMWEAVER is the main aspect of web design. Students can not only imitate the traditional drawing process through computer-aided design, but also save a lot of time than the traditional drawing method. Take the rendering of the effect diagram as an example. Traditional drawing may use paper, ruler, compass, pencil, needle pen, duckbill pen, marker, etc. The process includes making a draft, coloring, coloring, and also Repeated modifications and other specific operations. Computer-aided design provides reversible operation for the modification of the picture, which changes the workflow and method of art design, and greatly improves the work efficiency. In order to meet the needs of the society for talent training, in the current teaching system of Environmental art design design majors in higher education institutions in China, the proportion of computeraided design courses in all courses has gradually increased, and the cultivation of computer-aided design capabilities has been placed in an increasingly prominent position. on. However, it should also be noted that there are still many problems in the teaching of computer-aided design in the existing teaching system. 
Heavy skill training, light thinking training. This is concentrated in the disconnection between computer-aided design courses and environmental design creative thinking. Students are in a state of separation from computer-aided design courses and design-oriented courses. The rigorous computer-aided design methods have not been effectively used in the specific design practice. This is very evident in the student's design work: the inconsistency with the gorgeous and exquisite performance is full of naive and wrong design ideas and a serious separation from the actual structure. These have seriously affected the quality of the transfer of talents from higher education institutions to society. The reason is that we emphasize too much specific operational skills in computeraided design teaching, ignoring the cultivation of students' modern design ideas and rigorous design thinking habits. As an auxiliary design tool, computers have unique advantages over their traditional drawing method tools. Computer-aided design can often be a difficult state that humans can't reach with human hands. But computers are the product of technology. No matter how the form changes, it can't replace human thinking. The rigorous training and training of students will enable students to benefit for the rest of their lives in the process of self-knowledge renewal in the future. In teaching, we must not exaggerate the role of computers, especially environmental design teaching, correctly understand the dialectical relationship between computers and people, and will not rely on computers to replace human thinking, nor will it exclude computer design.

There is a lack of systematic links between computer-aided design courses. In comparison, the environmental design major has a computer class of up to five courses, with more class hours and 12 class hours per week. However, the effect of teaching is not good. The reason is that there is no necessary coordination and cooperation between the courses, and no effective teaching system is formed. Some of the courses have duplicated content, while some of the knowledge points are left blank, and the necessary links between the courses are lacking. For example, learning from advanced modeling software 3DMAX to engineering structure software AUTOCAD is not only a change in modeling methods, but also a mutual change and connection between modeling thinking and structural thinking. If the time of the course arrangement is unreasonable, the content of the lectures cannot be organically combined. Undoubtedly, students will be confused about the concept of computer-aided design methods and the teaching effect will be greatly reduced.

At present, computer-aided design plays a major role in the background of Environmental art design design. Its ultimate goal is to serve the design. This is also our firm position. We must not equate computer-aided design with Environmental art design design. However, in the current computer-aided design course under the Environmental art design design major, there are more or less different levels of teaching misunderstanding: 1. The traditional teaching methods of traditional multimedia teaching methods are mainly based on traditional chalk board teaching and multimedia courseware. Too much reliance on multimedia courseware will make teachers and students lose their interactivity. It is difficult to give play to the leading role of teachers in the classroom and the main role of students. It is also difficult to include the software use required for related courses. It is difficult to interact with students in software learning. Coupled with limited class time, it is impossible for teachers to give each student individual counseling exercises. This will inevitably lead to problems in the practice of application software, lack of practical ability, knowledge. The acquisition is not comprehensive, and it is ultimately difficult to achieve the teaching purpose of the computer-aided design course. Design software version update speed the version of the computer-aided design software taught in the classroom is updated too fast. The software related to the computer-aided design course is the mainstream design software on the market. These softwares basically have strong practical functions, but it is because of the complexity of these software that blocks the enthusiasm of many students. In addition, These mainstream software are basically developed by foreign Autodesk companies or Adobe companies, and the English version is a lot of students. The software version is updated faster, and the software will be adjusted every year. As a result, some of the previous ideas and methods of production have been updated. Whether our teaching content can be updated in time according to the upgrade of the software version, students can learn some current production methods and production ideas, which is also a very serious problem we face. Short Course Time The computer-aided design course has a short course period. According to the author's teaching experience in the past few years, it is difficult for students to study the software in the computer-aided design course in such a short period of time. Take 3DS MAX 3D software, it takes at least two or three months to really reach the required level. Therefore, many students choose to continue their studies in computer training classes in the community. However, due to the social strength of teachers, teaching methods and other reasons, students do not learn very well. 4. Lack of scientific and targeted textbooks There are many kinds of textbooks on computer-aided design courses for Environmental art design design on the market, but most of them lack scientific and targeted. For example, only focusing on theory and lacking the necessary practical cases make the curriculum become empty preaching; too much emphasis on performance skills, ignoring the essence of design is to meet people's needs. In addition, there are many books on various types of software on the market and books on environmental design. However, there are not many books on computer-aided design courses for Environmental art design design. Many teachers are taught according to their own experience, resulting in poor teaching quality. Theoretical teaching is out of the actual situation Many teachers now graduate from college in the 1990s and are not very proficient in software. The insufficiency of the teacher's teaching with the actual case makes the course professor boring and boring, and the practicality is not enough; the student design is unconstrained and the normativeness is not strong, and the students who are trained are often unfamiliar with the design norms of the industry, so that the students are after entering the job. It is often necessary to accept retraining from the company. In-depth exploration of the art design industry can bring new design concepts into teaching. The design teacher puts a lot of energy into the theoretical teaching and has insufficient contact with the actual project. This requires our professional teachers 
to adapt to the development of the times and re-explore the practice business.

Students' understanding of this course is often misunderstood, that is, the use of software, neglecting the essence of design; excessive reliance on and emphasis on computer technology, resulting in the mediocrity of design works, the specific performance of the design works, lack of creativity and vision Impact; some students alone put a lot of after-school time on the self-study of software plug-ins, wasting a lot of valuable time, just neglecting the research on design innovation; once again, too much emphasis on student independence, often to a certain extent Ignore the cultivation of student team awareness. Today's corporate projects are completed by a team, and students often find their team's awareness after entering the company. In short, as a teaching of Environmental art design design in colleges and universities, it is necessary to grasp the types of software learned in the computer-aided design course at the macro level, and reexamine the original teaching mode in accordance with the characteristics of its own profession, in order to adapt to the new changes in the situation, New requirements and new development trends.

\section{REFORM OF COMPUTER AIDED DESIGN TEACHING}

To cultivate creative thinking as a teaching purpose. Computer-aided design provides us with a good platform to make hand-painted and difficult-to-express creative effects work in computers. But the computer is a tool after all. The real idea is the creative thinking of the person. Too much dependence on the computer makes the creative thinking of the person conservative and narrow. Therefore, in teaching, we must cultivate creative thinking as the fundamental purpose of teaching. In the formulation of teaching plans and syllabus and the implementation of specific teaching of the curriculum, it is necessary to put the instillation and cultivation of outstanding modern design thinking at the forefront. In the process of classroom teaching and assessment, students should be encouraged to innovate their thinking while strictly controlling all aspects of the environmental design practice process, so that students' creative thinking can be integrated in the long-term accumulation. First of all, in the computer design teaching, the teaching methods and means should be very flexible. Teachers should focus on inspiration and guidance, and encourage students to use any means that can be used to express the purpose of design and flexibly express various forms of creative ideas. Let students combine the design elements according to their personal thinking and aesthetic concepts to form more creative spaces with individuality. This will enable students to gradually develop the habit of thinking and creativity, which is conducive to future professional learning and design. Secondly, let students appreciate more and more good design works, listen to good academic lectures, and conduct academic exchanges with other schools to gradually cultivate their creative thinking. There are many kinds of scenes in nature, and there are thousands of shapes. How to exaggerate these forms and design them into good creative works, no creative thinking is impossible.
Adjust the course structure, introduce case teaching, and improve teaching measures. First of all, to change the state of separation between courses, we must re-revise the syllabus, systematically consider and strictly define the relationship between pre-requisite courses and follow-up courses, and strengthen the connection between computer-aided design courses and materials, engineering drawings and other related courses, so that they can be taught. The process interacts and complements each other to form an effective teaching system. It is necessary to modify the existing computer-aided design curriculum, adjust the course content, and integrate the more relevant courses. Each course should clarify the purpose of teaching and complement the computer-aided design curriculum to form a systematic, efficient, and in-depth course system. Secondly, the introduction of case-based teaching in teaching, the use of complete commercial design examples in computer-aided design teaching; at the same time in the design of commercial design courses through the specific design cases highlight the practical application of computer-aided design ideas in specific links To enable students to clearly understand the design process, the angle of thinking, and the method of solving problems. Through the case, students can clearly understand the formation process of the design plan and the problems that should be paid attention to in the actual work, so as to penetrate the computer-aided design technology. Go to all links.

Cultivate "double-type" teachers, strengthen communication and improve the level of teachers. At present, the prevailing phenomenon in colleges and universities is that design courses are taught by design professionals, while computer-aided design courses are undertaken by computer professionals. Due to the lack of in-depth understanding of the structure of environmental expertise, these professionals often cannot accurately grasp the knowledge needs of students. Although the lectures have a large amount of knowledge and depth, they have separated the relationship with Environmental art design design and cannot satisfy the ring art. The actual needs of professional students. Cultivating and introducing "double-type" teaching talents is an effective way to solve this problem. The "double-type" talents not only have a strong design theory level of the Environmental art design major, but also have rich practical design experience, and have the ability to provide students with a relatively complete knowledge system. Such talents need to be cultivated by universities to establish a relaxed and generous research and training environment. At the same time, it is also an important way to recruit some senior art designers with rich practical experience from the society to undertake some teaching tasks. In the absence of "double-skilled" teachers, it is also a practical way to strengthen communication between existing teachers. For example, teaching and research activities and teaching exchanges can be carried out on a regular basis to enable teachers to communicate and communicate together. The content can include teaching progress, teaching experience, and classroom feedback. Timely communication and communication can enable teachers to grasp the specific situation in a timely and comprehensive manner, and dynamically adjust the teaching methods and contents in real time, so that the entire circle art teaching system has real-time feedback ability, which will greatly improve the teaching effect. 


\section{DEVELOPMENT TREND OF COMPUTER-AIDED DESIGN COURSES FOR ENVIRONMENTAL ART DESIGN DESIGN}

The educator Mr. Tao Xingzhi once said: "Children are the main body of education. Education can't subjectively command everything, and it can be replaced." Quality education also requires teachers to be transformed from knowledge transmitters and indoctors into students' active learning helpers. promoters. In our traditional teaching, we use the infusion method, that is, the teacher finishes the lecture first, and then asks the questions for the students to answer. This will make the students feel very boring, and even do not want to think about the problem. Teachers are always in a dominant position, while students are in a passive position. The problem is the wave of classroom teaching and the prelude to the climax of classroom teaching. If there is a "problem", there will be an unknown, and there will be an expansion of teaching activities. While researching software and revealing software operation techniques, students' subjective status can be continuously strengthened. After students have mastered certain basic knowledge, they can further ask students to find ways and means to solve problems themselves, including learning from good technical students, accessing materials in libraries, and searching for useful information through the Internet. Students can force themselves to actively learn and train hard through various learning channels. This kind of active learning method is much better than the teacher's "cramming" in the classroom to convey knowledge and students passively accept knowledge. For example, the computer-aided design Photoshop software course begins with the second semester of the second year. This semester is mainly about the basics. If there is no such guidance, then what is teaching! So to make the course interesting and meaningful, it is necessary to know what kind of students we want to train in the courses we teach. What we need to cultivate is the talent that can meet the requirements of the company. Teaching out of the market will only make students tired of learning, because students don't know what the lessons they have learned. Therefore, in order to better achieve the teaching goals and cultivate outstanding students, we must keep abreast of the times and understand what kind of talents companies need today. Regarding the related software learned in the computer-aided design course, the positioning of the newly-employed students is relatively basic, and the work content is more auxiliary work, which means that students need to have solid basic skills and strong services. awareness. Therefore, the teaching of computer-aided design courses should focus on the foundation of students, and let students have a better sense of service and attitude in the subtle, and comprehensively improve the overall quality of students. There are also opportunities to increase student visits and participate in design companies, strengthen school-enterprise cooperation, and lead students to design companies, similar universities, and special minority buildings in special areas for study and study, learning from and drawing inspiration. In the overall design of the Environmental art design course, a certain amount of design practice courses, such as interior design, landscape design, outdoor design, public space design, etc., should be arranged according to the professional tendency, and it can also be combined with the design competition activities that are publicly collected in the society. Additional homework exercises. The advantage of this is that the design requirements of the design competition can be collected according to the society, and the appropriate design software and design method can be selected according to the needs of artistic creation and creativity, so that students can truly understand the auxiliary design function of the design software. If students receive a place award in the competition, it will increase their selfconfidence and reflect the importance of computer-aided design courses for students.

\section{CONCLUSION}

The teaching of computer-aided design courses should be constantly adjusted with the advancement of design concepts and technologies. It is also necessary to carry out teaching reforms in accordance with the needs of national curriculum construction, timely adjust teaching methods, research and solve problems in traditional teaching, and make classroom teaching more effective. Effectively, we must strengthen the cultivation of students' innovative ability and practical ability. In the end, we will seek effective teaching methods that can help students to find a smooth job. This is the direction that our teaching staff is constantly striving for. In the computer-aided design course, no matter what kind of software you are learning, three-dimensional, two-dimensional, although each has its own strengths, it is also a tool for us to use. If we are skilled in using them, we will create Work is good, software is just a tool, don't rely too much on technology when learning, and more often we need our beauty to determine the quality of the work.

\section{REFERENCES}

[1] Wu Xin. Reform and practice of computer-aided design integrated teaching mode for higher vocational gardens[J].Journal of Liaoning Agricultural Vocational and Technical College,2011,13(5):37-38.

[2] Tian Renyu. On the development of computer-aided design in higher vocational colleges [J]. Popular Literature: Academic Edition, 2011 (24) 250-250.

[3] Lu Yongquan. Research on Teaching Reform of Computer Aided Design Course in Vocational Colleges-Taking AutoCAD Course as an Example[J]. Modern Vocational Education, 2015, A0(22): 84-85.

[4] Wang Lifang. How to improve the teaching effect of AutoCAD in technical colleges [J]. Occupation, 2015, 9 (35): 112-113.

[5] Niu Zheng. Adapt to economic and social development, reform and adjustment of vocational education [J]. China Vocational and Technical Education, 1999 (10): 15-16.

[6] M. Young, The Technical Writer's Handbook. Mill Valley, CA: University Science, 1989. 